10 Pro

derzhavno-pryvatne partnerstvo: Zakon Ukrajiny vid 1 lypnja 2010 roku \# 2404-VI [On public-private partnership: Law of Ukraine dated July 1, 2010 No. 2404VI]. Available

at: http://zakon2.rada.gov.ua/laws/show/2404-17.

11 Realizacija proektiv derzhavnopryvatnogho partnerstva $v$ Ukrajini: praktychnyj posibnyk [Realization of PublicPrivate Partnership Projects in Ukraine: A Practical Guide]. Available at: https://mtu.gov.ua/files/Посібник\%20Реаліза ція\%20ДПП\%20в\%20Україні.pdf.

12 Dovidka shhodo rezuljtativ zdijsnennja DPP (1 pivrichchja 2018 rik) [Reference on the results of the PPP (1st half of 2018)]. Available at:
http://www.me.gov.ua/Documents/Print?lang= uk-UA\&id=62a9b6fb-27ff-462a-b351-

eeeadfb26b6f

13 Morozova N.I. (2013) Rol' gosudarstvenno-chastnogo partnerstva $\mathrm{V}$ formirovanii i realizatsii sotsial'no orientirovannoy politiki Rossii [The role of public-private partnership in the formation and implementation of socially oriented Russian policy]. European perspectives. No. 6, pp. 512.

14 Gosudarstvenno-chastnoe partnerstvo: ucheb. posobie dlya bakalavriata $\mathrm{i}$ magistratury (2016) [Public-private partnership: studies. manual for undergraduate and graduate]. M.: Publishing Yurayt. (in Ukrainian)

\title{
БЕЗПЕКА ГОТЕЛЬНИХ КОМПЛЕКСІВ ЯК СКЛАДОВА ЕФЕКТИВНОСТІ ТУРИСТИЧНОГО МЕНЕДЖМЕНТУ ТА ПРИВАБЛИВОСТІ ТУРИСТИЧНИХ ПІДПРИЕМСТВ ДЛЯ ВІТЧИЗНЯНИХ ТУРИСТІВ (НА ПРИКЛАДІ ТУРЕЧЧИНИ)
}

\author{
Козлова А.О. к.е.н., ст. викладач (ХНУМГ імені О.М. Бекетова)
}

В статті обтрунтовано необхідність забезпечення життєво важливих інтересів туриста (особи) під час перебування в краӥні відпочинку, а саме безпеки перебування в готелі. Встановлено, щэо важливу роль у забезпеченні безпеки туристів відіграє менеджмент готельних комплексів та туристичних операторів. Констатовано, щзо не тільки менеджмент туристичної галузі повинен опікуватися розв'язанням ичих питань, а й органи влади і управління держави, правоохоронці, як провідники начіональних інтересів, в тому числі економіки країни. Зроблено висновок про намагання державних інституціий окремих держав покращчтти стан безпеки перебування туристів в країні за рахунок втілення сучасних технологій $і$ стандартів. Запропоновані нові, нестандартні форми і підходи щэодо поліпшення стану безпеки туристичного середовища.

Ключові слова: туризм, туристичні потоки, готелі, менеджмент муристичної галузі, безпека туристів, безпека готелів, охорона готелів, якість послуг. 


\title{
БЕЗОПАСНОСТЬ ГОСТИНИЧНЫХ КОМПЛЕКСОВ КАК СОСТАВЛЯЮЩАЯ ЭФФЕКТИВНОСТИ ТУРИСТИЧЕСКОГО МЕНЕДЖМЕНТА И ПРИВЛЕКАТЕЛЬНОСТИ ТУРИСТИЧЕСКИХ ПРЕДПРИЯТИЙ ДЛЯ ОТЕЧЕСТВЕННЫХ ТУРИСТОВ (НА ПРИМЕРЕ ТУРЦИИ)
}

\author{
Козлова А.А., к.э.н., ст.преподаватель (ХНУГХ имени А.Н. Бекетова)
}

В статье обоснована необходимость обеспечения жизненно важных интересов туриста во время пребывания в стране отдыха, а именно безопасности пребывания в отеле. Установлено, что важную роль в обеспечении безопасности туристов играет менеджмент гостиничных комплексов и туристических операторов. Констатировано, что не только менеджмент туристической отрасли должен заниматься решением этих вопросов, но и органы власти и управления государства, правоохранители, как проводники интересов, в том числе экономики страны. Сделан вывод о попытке государственных институтов отдельных государств улучшить состояние безопасности пребывания туристов в стране за счет внедрения современных технологий $и$ стандартов. Предложены новые, нестандартные формы и подходы по улучшению состояния безопасности туристической среды.

Ключевые слова: туризм, туристические потоки, гостиницы, менеджмент туристической отрасли, безопасность туристов, безопасность гостиниц, охрана отелей, качество услуг.

\section{SAFETY OF HOTEL COMPLEXES AS A COMPLEX OF THE EFFICIENCY OF TOURISM MANAGEMENT AND ATTRACTIVENESS OF TOURISM ENTERPRISES FOR DOMESTIC TOURISTS (IN THE EXAMPLE OF TURKEY)}

\author{
Kozlova A.O., PhD in Economic \\ (O.M. Beketov National University of Urban Economy in Kharkiv )
}

The article substantiates the need to ensure the vital interests of the tourist while staying in a country of rest, namely the security of the stay at the hotel. The management of hotel complexes and tour operators plays an important role in ensuring the safety of tourists. It was stated that not only the management of the tourism industry should take care of the solution of these issues, but also the authorities and government, law enforcement, as leaders of national interests, including the economy of the country. It is proved that the efforts of state institutions of certain states to improve the safety of stay of tourists in the country through the implementation of modern technologies and standards. New, non-standard forms and approaches for improving the safety of the tourist environment are offered. The conclusion is made about the expediency of the priority implementation of such activities: explanatory and preventive work with clientstourists; providing information to the tourist by the hotel guide at an information meeting on the rules of safety and behavior in case of emergency, to whom to contact at the same time, from whom to expect help; providing information to the tourist about the possible negative consequences in case of visiting potentially dangerous places; exchange of information about new forms of dangers for tourists that may arise, or specific, inherent in a particular country; search for forms of more fruitful cooperation between tourist agencies and authorities, law enforcement. The necessity of formation of an effective system of security of tourism business at

Вісник економіки транспорту і промисловості № 65, 2019 
the local level (travel Agency or Agency, hotel, tour operator, tourist carrier) and the state level with the use of modern security technology.

Key words: tourism, tourist streams, hotels, tourist industry management, tourists safety, hotel safety, hotel security, quality of services.

Постановка проблеми та її зв'язки з науковими чи практичними завданнями. Туризм - тимчасовий виїзд особи 3 місця проживання в оздоровчих, пізнавальних, професійно-ділових чи інших цілях без здійснення оплачуваної діяльності в місці, куди особа від'їжджає [1].

3 початку XXI століття у світі зафіксовано зростання туристичних потоків, особливо до країн які пропонують доступний туристичний продукт за ціною, якістю, логістикою.

Традиційно привабливою країною у туристів пострадянського простору $\epsilon$ Туреччина, яка одна із перших у світі активно почала втілювати нові туристичні технології, які потім трансформувалися в світові стандарти. Країна активно розвиває туристичну галузь на протязі декількох десятиліть, а доход від туристичної діяльності займає значний відсоток $\mathrm{y}$ державному бюджеті.

Так, за останні п'ятнадцять років нового тисячоліття туристичний потік до Туреччини збільшився з 15 до більш як 38 млн. туристів на рік. За даними Міністерства культури i туризму Туреччини лише за першу половину 2018 року у порівнянні з аналогічним періодом 2017 року країну відвідало на 32,55 \% більше туристів. А 2017 рік від туристичної діяльності Туреччина отримала дохід у розмірі 26,2 млрд. дол. США. При цьому, туристи 3 кожним роком стали менше витрачати (середній чек туриста в Туреччині в 2017 році складає 681 дол. США [2]. Незважаючи на зростаючу жорстку конкуренцію на ринку надання туристичних послуг, виникнення нових туристичних напрямків, а інколи, незважаючи і на демпінгові заходи нових конкурентів, Туреччина залишається провідною туристичною країною світу та впевнено збільшує туристичні потоки.
Причин тому декілька, не завжди залежних від Туреччини, інколи протилежного або взаємовиключаючого характеру, наприклад це:

- $\quad$ підвищення рівня купівельної спроможності окремих суспільних прошарків (тобто ті особи, які раніше не могли собі дозволити відпочинок за кордоном, отримавши додаткові фінансові надходження отримали можливість відвідати певні країни);

- $\quad$ зниження рівня купівельної спроможності окремих суспільних прошарків (тобто ті особи, які раніше собі дозволяли відпочинок за кордоном на екзотичних курортах або на курортах європейських країн, значно втративши фінансові надходження не можуть і не хочуть відмовитися від відпочинку за кордоном та обирають пріоритет між сервісом і ціною);

- $\quad$ утримання сервісу на високому рівні, пошук нових форм підвищення доступності та привабливості курортного відпочинку в таких країнах як, наприклад, Туреччина, Сгипет;

- $\quad$ спрощення прикордонних та митних процедур, або процедур візового характеру;

- $\quad$ втрата або переформатування традиційно привабливих курортів (для України, це наприклад тимчасова втрата Криму);

- толерантне відношення до відпочиваючих з боку влади і місцевого населення;

- приваблива логістична складова (відносно нетривалий час в дорозі, прямі чартерні авіарейси, зручні трансферні умови);

- $\quad$ заборона урядами деяких країн 3 політичних або інших мотивів відвідування своїми громадянами окремих країн, що раніше вважалися небезпечними, 
a це призвело до перерозподілу туристичних потоків вже до інших країн, в тому числі до Туреччини;

- майже відсутність мовного бар'єру та наявність системи «all inclusive», тощо.

В той же час, жорстка конкуренція на ринку надання туристичних послуг, нові ризики та загрози як зовнішнього та внутрішнього характеру, вимагають від туристичних операторів та менеджменту готельних комплексів не тільки пристосовуватися до існування в сучасних умовах, а й вимагають покращення умов для туристів, нових підходів до управління якістю відпочинку.

Аналіз останніх досліджень i публікацій. Питанням якості, формування системи управління якістю присвятили свої праці Е. Демінг, Дж. Джуран,

Ільєнкова, К. Ісікава, Ф. Котлер, Ф. Кросбі, С. Скобкін, Ф. Тейлор, Дж. Уокер [4-12] та інші, а серед вітчизняних дослідників цим питанням займалися В. Дикань, П. Калита, Н. Кудла, I. Писаревський, Т. Сокол, Б. Мунін, М. Шаповал [13-20] та інші. В роботах вищенаведених авторів увага приділялася таким поняттям як «якість», «якість послуг», побудові системи управління якістю. В той же час, дані поняття розглядаються ними переважно в загальному аспекті, без урахування специфічних умов діяльності готельних комплексів, без вивчення впливу на них нових ризиків, насамперед безпекової складової, в сучасних умовах розвитку туристичної галузі.

Метою статті с визначення нових підходів і напрямків поліпшення ефективності туристичного менеджменту, перш за все, шляхів поліпшення рівня безпеки туристського середовища як ключового фактору привабливості в туристичній галузі та оцінки якості наданих послуг готельної установи.

Виклад основного матеріалу. Аналіз попиту на туристичному ринку свідчить про те, що турист при виборі тура перше на що звертає увагу є ціна, рівень сервісу, трансферні послуги, привабливість екскурсійної програми [22]. При цьому, безпека туристів в країні перебування для наших співвітчизників $є$ традиційно не першочерговою умовою. В той же час, для туристів 3 країн Європейського Союзу, Великобританії чи США безпекова складова $\epsilon$ однією із першочергових умов повноцінного і якісного відпочинку.

Нажаль на території країн, найбільш популярних у вітчизняних туристів, таких як Єгипет, Туреччина, Таїланд, Шрі-Ланка налічуються осередки озброєних конфліктів, ознак громадянського або військового конфліктів. Незважаючи на заходи 3 безпеки, які зараз запроваджуються в туристичному бізнесі, вони не завжди $\epsilon$ ефективними i не гарантують туристам безпеку навіть під час перебування в закритому середовищі (готель, аеропорт, під час пересування в транспортному засобі й т. ін.). Охорона в готелях, в місцях скупчення туристів не $\epsilon$ запорукою захисту від нападу як з боку організованих злочинних угрупувань так і 3 боку окремих осіб. Підтвердженням тому $\epsilon$ той факт, що за останній період часу у Єгипті та Туреччині скоєні терористичні акти безпосередньо в готелях. Причому, теракти здійснювалися як в невеликих готелях нижчого рівня сервісу, так і в всесвітньо відомих готелях найвищого рівня сервісу. В якості прикладу можна навести серію терактів які сталися в жовтні 2004 року в місті Таба (Сгипет) в 5-ти зірковому готелі всесвітньо відомої мережі «Hilton», в результаті чого загинуло 44 особи та було поранено більше 270 осіб 3 різних країн світу. В липні 2017 році в місті Хургада (Сгипет) терористом було здійснено напад на туристів в готельному комплексі, в результаті чого двоє українських туристів загинули, ще чотири було поранено. В січні цього ж 2017 року в популярному серед наших співвітчизників місті Ізмір (Туреччина) теж було здійснено напад, який був кваліфікований як злочин. 
Можна 3 впевненістю констатувати, що такі ганебні явища як теракт, напад на людей з релігійних чи політичних мотивів, 3 метою пограбування $є$ об'єктивною реальністю сучасності та не оминає країни і Європейського Союзу, і Сполучених штатів чи Великої Британії.

Як слідство, наявність наведених для туристів загроз спонукає як менеджмент готелів, так і уряди країн посилювати не тільки фізичну охорону, а й підвищувати заходи безпеки взагалі, розробляти і впроваджувати нові безпекові стандарти в туристичній галузі. Для цього все частіше використовуються можливості державних і правоохоронних органів, які використовують удосконалену правову та матеріальну бази, спеціальне обладнання та озброєння, професіоналів високого рівня. I це $\epsilon$ позитивним фактором, що призводить до покращення кінцевого результату безпеки середовища, безпеки туристів.

Так, одним 3 прикладів посилення 3 боку держави уваги до безпеки туристів та гостей країни $є$ Туреччина, яка запровадила 31 січня 2019 року податок на безпеку для туристів в розмірі 1,5 євро, що стягується в аеропортах при прильоті [3].

Помилково вважається що заходи 3 безпеки та робота 3 їх реалізації $\epsilon$ завданням тільки для менеджменту готелів. Так, від якісної, високопрофесійної та ефективної системи безпеки готелю залежить дуже багато, а менеджмент готелю повинен приділяти безпеці туристів i персоналу значну увагу. Як вже відмічалося, система безпеки в готелях включає багато компонентів, а це і люди (служба охорони), і технічні пристрої, сейфи, і системи відео спостереження тощо. $\mathrm{B}$ той же час безпека не може забезпечуватися лише за рахунок гостей, туристів [17].

Туристичні оператори, менеджмент туристичних агенцій та структур, які з ними співпрацюють теж повинні активніше «включатися» в цю роботу. Мова йдеться, перш 3 все, про дії які не потребують значних додаткових фінансових затрат, а саме про [17, 21-22]:

\section{- роз'яснювально-}

профілактичну роботу 3 клієнтамитуристами (наприклад: доведення туристу при придбанні туру правил безпеки в конкретній країні, надання інформації про поведінку у разі потрапляння у надзвичайну ситуацію та контакти органів влади, рятувальних служб, правоохоронців тощо);

- $\quad$ надання інформації туристу готельним гідом на інфозустрічі, не тільки про умови, сервіс, послуги і можливості конкретного готелю, а й правил безпеки та поведінки у разі потрапляння у надзвичайну ситуацію, до кого звертатися при цьому, від кого очікувати на допомогу;

- $\quad$ надання туристу інформації про можливі негативні наслідки у разі відвідування потенційно-небезпечних місць, при переміщенні країною, про наявність або відсутність охорони в цих місцях чи при пересуванні тощо;

- обмін інформацією щодо нових форм небезпек для туристів, які можуть виникнути, або специфічних, притаманних конкретній країні, для врахування цієї інформації при підборі туру та умов для туристів (наприклад, включаючи інформацію про готелі 3 низьким рівнем безпеки перебування для туристів чи наявність поблизу готелів небезпечних в криміногенному плані місць чи осередків злочинності);

- $\quad$ пошук форм більш плідної взаємодії між туристичними установами i органами влади, правоохоронцями (наприклад, на рівні консульських структур міністерства закордонних справ, аналітичних підрозділів та підрозділів зв'язків 3 громадкістю міністерства внутрішніх справ тощо).

$$
\text { Слід зауважити, що тільки }
$$
вищенаведеними заходами обмежитися не вдасться. Необхідна ефективна система безпеки, як на локальному рівні, про що йдеться вище (туристична фірма чи агенція, готель, туроператор, туристичний 
перевізник), так і на державному рівні із застосуванням сучасних технологій, а це неможливо без додаткових джерел фінансування.

На нашу думку цього можна досягнути не за рахунок туристів, а шляхом, хоча б, часткового фінансування безпекових заходів з бюджету приймаючої країни, чи за рахунок частки прибутку туристичного оператора. Аргументом для цього $\epsilon$ те, що у разу зменшення або припинення туристичного потоку бюджет країн для яких туристичний бізнес $\epsilon$ важливою статтею доходів до держбюджету втратить значно більше, а діяльність туроператора у разі зникнення попиту на туристичний продукт може призвести до їх банкрутства взагалі.

Висновки. Таким чином, досягти високого рівня безпеки готельного господарства, туристичної галузі можливо за умови комплексного підходу до вирішення вищенаведених проблем на системній основі, ключовою умовою якого $\epsilon$ ефективність туристичного менеджменту, участь в цьому процесі державних органів і залучення достатнього фінансового забезпечення. В сучасних умовах туристичного ринку безпека готельних послуг перейшла 3 рівня другорядного до рівня важливого і необхідного. Результат не піддається сумніву: на безпеці людей заощаджувати не повинні а ні туристи, а ні туристичні установи, а ні держава.

\section{ПЕРЕЛІК ВИКОРИСТАНИХ ДЖЕРЕЛ}

1. Про туризм : Закон України від 15.09.1995 № 324-95-ВР // Відомості Верховної Ради України (ВВР). - 1995. - № 31. - ст. 241.

2. Сапожников И. Турция опубликовала точное количество туристов за 2017 год. [Електроний ресурс] - Режим доступу: newsturk.ru> 2018/01/31>tyrsiyaopu...

3. Количество туристов в Турции увеличилось на треть [Електроний ресурс] - Режим доступу: www.aa.com.tr /tr/turkiye/dis-hat-yolcularindan-alinacaguvenlik-vergisi-dusuruldu/ 1349993

4.Деминг Э. Выход из кризиса.

Новая парадигма управления людьми, системами и процессами / Э. Деминг - М.: «Альпина Паблишер», 2011. - 400 с.

5. Джуран Дж. Качество в истории цивилизации. Эволюция, тенденции и перспективы управления качеством / Дж. Джуран. - М. : РИА «Стандарты и качество», 2004. - 208 с.

6.Исикава К. Японские методы управления качеством /К. Исикава.- М.: Экономика, 1988. - 215 с.

7.Гуру менеджмента качества и их концепции: пер. с анг. / Э. Деминг, Дж. Джуран, Ф. Кросби, К. Исикава - М.: ИМЭМО, 2003. - 250 с.

8.Управление качеством: учебник / С.Д. Ильенкова, Н.Д. Ильенкова, С.Ю. Ягудин и др.; Под ред. доктора экономических наук, профессора С.Д. Ильенковой. -М.: ЮНИТИ. - 194 с.

9.Маркетинг. Гостеприимство. Туризм / Ф. Котлер, Д. Боуэн, Д. Мейкенз: [пер. с англ.]. - М: ЮНИТИ, 1998. - 204 с.

10. Скобкин С.С. На пути к качеству / С.С. Скобкин // Парад отелей. 2004. - № 4. - С. 25-30.

11. Тэйлор Ф.У. Научная организация труда / Ф.У. Тэйлор; предис. П.М. Керженцева; Пер. с англ. - 2 изд-е. М.: НКПС; Транспечать, 1925. - 276 c.

12. Уокер Дж. Введение в гостеприимство: учебн. пособие. / Пер. с англ. -2-е изд. - М.: ЮНИТИ-ДАНА, 2002. $463 \mathrm{c}$.

13. Дикань В. Управління якістю як фактор конкурентоспроможності підприємств / В. Дикань // Економіка України. -1996. -№1-С.43-48.

14. Дикань В.Л. Сучасні системи управління якістю продукції / В.Л. Дикань, Н.М. Лисьонкова // Вісник економіки транспорту та промисловості: збірник наук.-практ. ст. - Х.: УкрДАЗТ, 2005. - Вип. 12. - С. $229-235$. 
15. Калита П. Система управління якістю: «за стандартом» чи за специфікою підприємства? / П. Калита // Світ якості України. - 2010. - № 3. - С. 102-104.

16. Кудла Н.С. Управління якістю в туризмі: підручник / Н.С. Кудла - К.: «Центр учбової літератури», 2015. - 328 с.

17. Організація обслуговування у малих готелях: навчальний посібник / упоряд. Г.Б. Мунін. - К.: Видавництво Європейського університету, 2007. - 181 с.

18. Організація

туризму: підручник / I.M. Писаревський, С.О. Погасій, М.М. Поколодна та ін.; за ред. I.М. Писаревського. - Х.: ХНАМГ, 2008. $541 \mathrm{c}$.

19. Сокол Т.Г. Організація обслуговування в готелях і туристичних комплексах / Т.Г. Сокол. - К.: Альтепрес, 2009. $-447 \mathrm{c}$.

20. Шаповал M.I. Менеджмент якості: підручник / M.І. Шаповал. - 3-те вид., випр. і доповн. - К.: Знання, 2007. $471 \mathrm{c}$.

21. Економічна безпека суб'єктів господарської діяльності в умовах глобальної фінансової кризи: монографія / O.А. Кириченко, О.I. Захаров, М.П. Денисенко та ін. - К.: ТОВ «Дорадо-Друк», 2010. - 412 c.

22. Чередниченко А.О. Якість надання послуг як ключовий фактор привабливості підприємств готельного господарства / А.О. Чередниченко, М.В. Калинин //Вісник економіки транспорту і промисловості. - 2016. - №56. - C. 88-96.

\section{REFERENCES}

1.Pro turyzm : Zakon Ukrajiny vid 15.09.1995 \# 324-95-VR [On Tourism: Law of Ukraine dated September 15, 1995 No. 32495-VR]. Information from the Verkhovna Rada of Ukraine. No. 31.

2.Sapozhnikov I. (2017) Turtsiya opublikovala tochnoe kolichestvo turistov za 2017 god. [Turkey has published the exact number of tourists for 2017 Available at: newsturk.ru> 2018/01/31>tyrsiya-opu...

3.Kolichestvo turistov $v$ Turtsii uvelichilos' na tret' ${ }^{\prime}$ The number of tourists in Turkey has increased by a third]. Available at: www.aa.com.tr/tr/turkiye/dis-hatyolcularindan-alinaca-guvenlik-vergisidusuruldu/ 1349993

4.Deming E. (2011) Vykhod iz krizisa. Novaya paradigma upravleniya lyud'mi, sistemami $i$ protsessami [Overcoming the crisis. New paradigm of managing people, systems and processes]. M $\quad . \quad$ "Alpina Publisher". (in Russian)

5. Dzhuran Dzh. (2004) Kachestvo v istorii tsivilizatsii. Evolyutsiya, tendentsii $i$ perspektivy upravleniya kachestvom [Quality in the history of civilization. Evolution, trends and prospects of quality management]. $\mathrm{M}$.: RIA "Standards and Quality". (in Russian)

6.Isikava K. (1988) Yaponskie metody upravleniya kachestvom [Japanese methods of quality management]. Japanese methods of quality management, (in Russian)

7.Deming E., Dzhuran Dzh., Krosbi F., Isikava K. (2003) Guru menedzhmenta kachestva i ikh kontseptsii: per. s ang. [Guru of quality management and their concepts: Per. from ang]. M .: IMEMO. (in Russian)

8.Il'enkova S.D., Il'enkova N.D.,. Yagudin S.Yu i dr. Upravlenie kachestvom: uchebnik [Quality management: a textbook]. M.: UNITY. (in Russian)

9.Kotler F., Bouen D., Meykenz D. (1998) Marketing. Gostepriimstvo. Turizm [per. s angl.] [Marketing. Hospitality. Tourism [trans. from English]] M.: UNITY. (in Russian)

10. Skobkin S.S. (2004) Na puti k kachestvu [On the road to quality]. Parade of hotels. No. 4.

11. Teylor F.U. (1925) Nauchnaya organizatsiya truda [Scientific Labor Organization]. M : NKPS; Translate. (in Russian)

12. Walker J. (2002) Vvedenie v gostepriimstvo: uchebn. Posobie. Per. s angl. 2-e izd [Introduction to hospitality: textbook. 
Allowance. Per. from English -2 ed]. M .: UNITY-DANA

13. Dykan V. Upravlinnja jakistju jak faktor konkurentospromozhnosti pidpryjemstv [Quality management as a factor of competitiveness of enterprises] / В. Дикань // Економіка України. -1996. -№1-С.43-48.

14. Dykan V.L., Lysjonkova N.M. (2005) Suchasni systemy upravlinnja jakistju produkciji [Modern quality management systems]. The bulletin of Transport and Industry Economics. No. 12, pp. 229 - 235.

15. Kalyta P. (2010) Systema upravlinnja jakistju: «za standartom» chy za specyfikoju pidpryjemstva? [Quality management system: "according to the standard" or the specifics of the enterprise?]. The world of quality of Ukraine. No. 3, pp. 102-104.

16. Kudla N.Je. (2015) Upravlinnja jakistju $v$ turyzmi: pidruchnyk [Quality management in tourism: a textbook]. $\mathrm{K}$.: "Center for Educational Literature". (in Ukrainian)

17. Munin Gh.B.

(2007) Orghanizacija obslughovuvannja u malykh ghoteljakh: navchaljnyj posibnyk [Organization of service in small hotels: a manual]. $\mathrm{K}$ : Publishing House of the European University. (in Ukrainian)
18. Pisarevsky I.M., Poghassi S.O., Pocolodn M. M. etc. (2008) Orghanizacija turyzmu: pidruchnyk [Tourism organization: a textbook]. X .: KNOW (in Ukrainian)

19. Sokol T.G. (2009) Orghanizacija obslughovuvannja $v$ ghoteljakh $i$ turystychnykh kompleksakh [Organization of service in hotels and tourist complexes]. K .: Altepres. (in Ukrainian)

20. Shapoval

M.I. (2007) Menedzhment jakosti: pidruchnyk [Quality Management: Tutorial]. K.: Knowledge. (in Ukrainian)

21. Kyrychenko O.A., Zakharov O.I., Denysenko M.P. ta in. (2010) Ekonomichna bezpeka sub'jektiv ghospodarsjkoji dijaljnosti v umovakh ghlobaljnoji finansovoji kryzy: monoghrafija [Economic security of economic entities in the context of the global financial crisis: a monograph]. K.: Dorado-Print Ltd. (in Ukrainian)

22. Cherednychenko A.O., Kalynyn M.V. (2016) Jakistj nadannja poslugh jak kljuchovyj faktor pryvablyvosti pidpryjemstv ghoteljnogho ghospodarstva [The quality of service provision as a key factor in the attractiveness of the hotel industry]. The bulletin of Transport and Industry Economics. No. 56, pp. 88-96.

\title{
НЕОБХІДНІСТЬ ФОРМУВАННЯ ПОЗИТИВНОГО ІМІДЖУ ПІДПРИЕМСТВА ЯК ІНСТРУМЕНТУ ВНУТРІШНЬОГО СТРАТЕГІЧНОГО УПРАВЛІННЯ
}

\author{
Чупир О.М., д.е.н., доцент, професор (ХНУБА)
}

\begin{abstract}
У статті розглянуто значення та сутність використання позитивного іміджу для підприємства, обгрунтовано доцільність його створення. Акцентовано увагу на узагальненні факторів, які впливають на створення позитивного іміджу підприємства, на виконанні певних задач щодо його досягнення. Розроблено модель формування позитивного іміджу підприємства в умовах сучасного економічного становища, щуо дасть можливість не тільки підвищити ефективність роботи
\end{abstract}

